\title{
Description of a new species and new records of some species of the genus Gnaphosa (Araneae: Gnaphosidae) from east Palaearctic
}

\author{
Yuri M. Marusik ${ }^{1} \&$ Seppo Koponen ${ }^{2}$ \\ ${ }^{1}$ IBPN RAS, Portovaya Str. 18, Magadan 685000, Russia \\ E-mail: ibpn@online.magadan.su \\ ${ }^{2}$ Zoological Museum, University of Turku, FIN-20014 Turku, Finland \\ E-mail: sepkopo@utu.fi
}

\begin{abstract}
Gnaphosa banini sp. n. (占우) from Mongolia, belonging to the borea species group, is described and diagnostic drawings of males of the borea group are given: borea Kulczyński 1908, chola Ovtsharenko \& Marusik 1988, microps Holm 1939 and orites Chamberlin 1922. Males of G. ilika Ovtsharenko et al. 1992 and G. pseudoleporina Ovtsharenko et al. 1992 are illustrated. Biogeographically interesting records are given for nine additional species of Gnaphosa from the eastern Palaearctic.
\end{abstract}

Key words - Gnaphosa, Gnaphosidae, spiders, east Palaearctic, new species, distribution, taxonomy

\section{Introduction}

Because of the two revisions by Platnick and collaborators (Platnick \& Shadab 1975; Ovtsharenko et al. 1992) Gnaphosa is, perhaps, one of the best known large genus of spiders in the Holarctic. It includes approximately 130 species (cf. Platnick 2000). Since the last revision of the eastern Palaearctic fauna (Ovtsharenko et al. 1992) only four species of Gnaphosa have been described (cf. Platnick 2000).

While surveying several collections in Novosibirsk, Turku and Magadan we found one new species of Gnaphosa from Mongolia and several zoogeographically interesting records for other Gnaphosa species. The goal of this work is to describe the new species of Gnaphosa and some other poorly known species, and to provide new interesting records.

Abbreviations used are as follows: $\mathrm{AB}$ - apophysis of embolic base, D - first description, Em - embolus, ET - embolic tooth, MA - median apophysis, $\mathrm{p}$ - prolateral, $\mathrm{r}$ retrolateral, S - synonymization, v - ventral. Measurements are in millimeters. Material treated herein is shared between the following museums: AMNH - American Museum of Natural History, New York; HMNH - Hungarian Museum of Natural History, Budapest; IBPN - Institute for Biological Problems of the North, Magadan; ISEA - Institute for Systematics and Ecology of Animals, Novosibirsk; JWC -
Jorg Wunderlich personal collection, later probably Senckenberg Museum; MMUM - Manchester Museum, University of Manchester; NRS - Naturhistoriska Riksmuseet, Stockholm; ZMMU - Zoological Museum of Moscow University; ZMUH - Zoological Museum, University of Helsinki; ZMUT - Zoological Museum, University of Turku.

\section{Survey of species}

Gnaphosa banini sp. n.

(Figs. 1-3, 9-10. Map 1)

Gnaphosa cf. microps: Marusik \& Logunov, 1998, p. 238.

Material. MONGOLIA: Holotype $\hat{\delta}$ (JWC) together with 7샤 \& 6우 paratypes (ZMMU, MMUM \& AMNH) [11] Bayankhongor Aimak, Gurvanbulag Somon, Khokh-Nuur (Lake), 47³2'N, 98³2'E, 2600-3000 m, 7-10.06.1997 (Yu. M. Marusik); 6今 (ZMUT \& NRS) [12] Arkhangai Aimak, Ondrer-Ulaan, Tsakhir, Chulut gorge, $48^{\circ} 07^{\prime} \mathrm{N}, 100^{\circ} 22^{\prime} \mathrm{E}$, $2100 \mathrm{~m}$, pitfall traps, 10-13.06.1997 (Yu. M. Marusik).

Diagnosis. Males of G. banini sp. n. can be easily distinguished from sibling species ( $G$. orites, $G$. microps, G. chola, and G. borea) shown in Figs. 4-8 by apophysis of embolic base which is elongate, parallelsided with bill-shaped tip, and inner position of embolic tubercle (Figs. 1-3). Females are similar to those of $G$. microps Holm, from which they can be distinguished by somewhat angled lateral pockets in the mid part and 


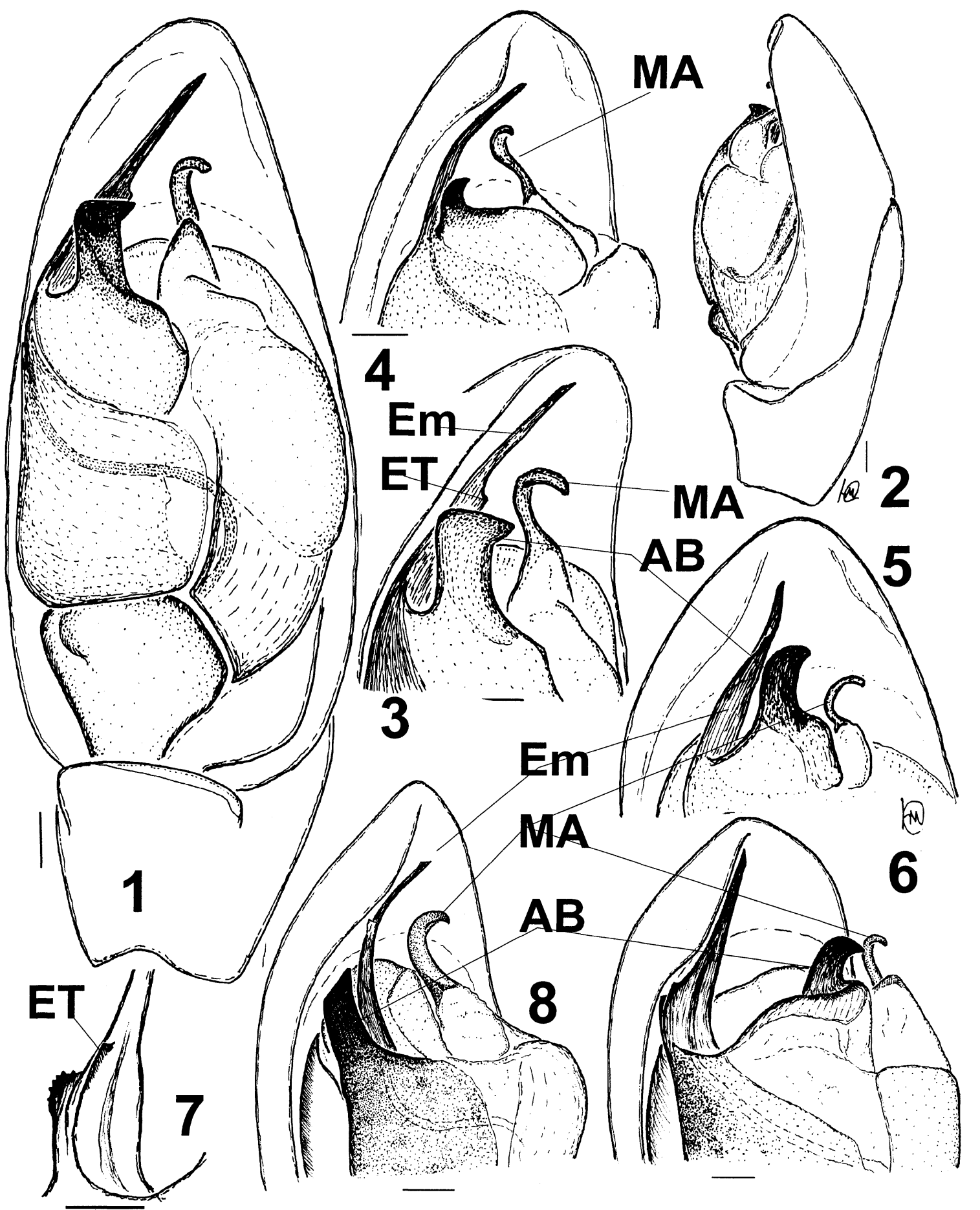

Figs. 1-8. Male left palp of Gnaphosa banini sp. n. (paratype) (1-3), G. orites (4), G. microps (5), G. chola (6-7) and G. borea (8). - 1, ventral view; 2, retrolateral view; 3-6 and 8. apical half of palp, ventro-prolateral view; 7, basal part of embolus showing embolic tooth and ridge. 4 and 5, specimens from Lapland; 6-8, specimens from Magadan. Scales: $0.1 \mathrm{~mm}$. Abbreviations: AB - apophysis of embolic base; Em - embolus, ET embolic tooth, MA - median apophysis.

relatively wider fovea (3 times wider than scape).

Description. Male. Total length 7.3. Carapace 3.2 long, 2.7 wide. Femur II 1.9 long. Eye sizes and interdistances: AME 0.08, ALE 0.13, PME 0.09, PLE 0.10, AME-AME 0.09, AME-ALE 0.03, PME-PME 0.09, PME-PLE 0.16, ALE-PLE 0.16, MOQ 0.31, front 


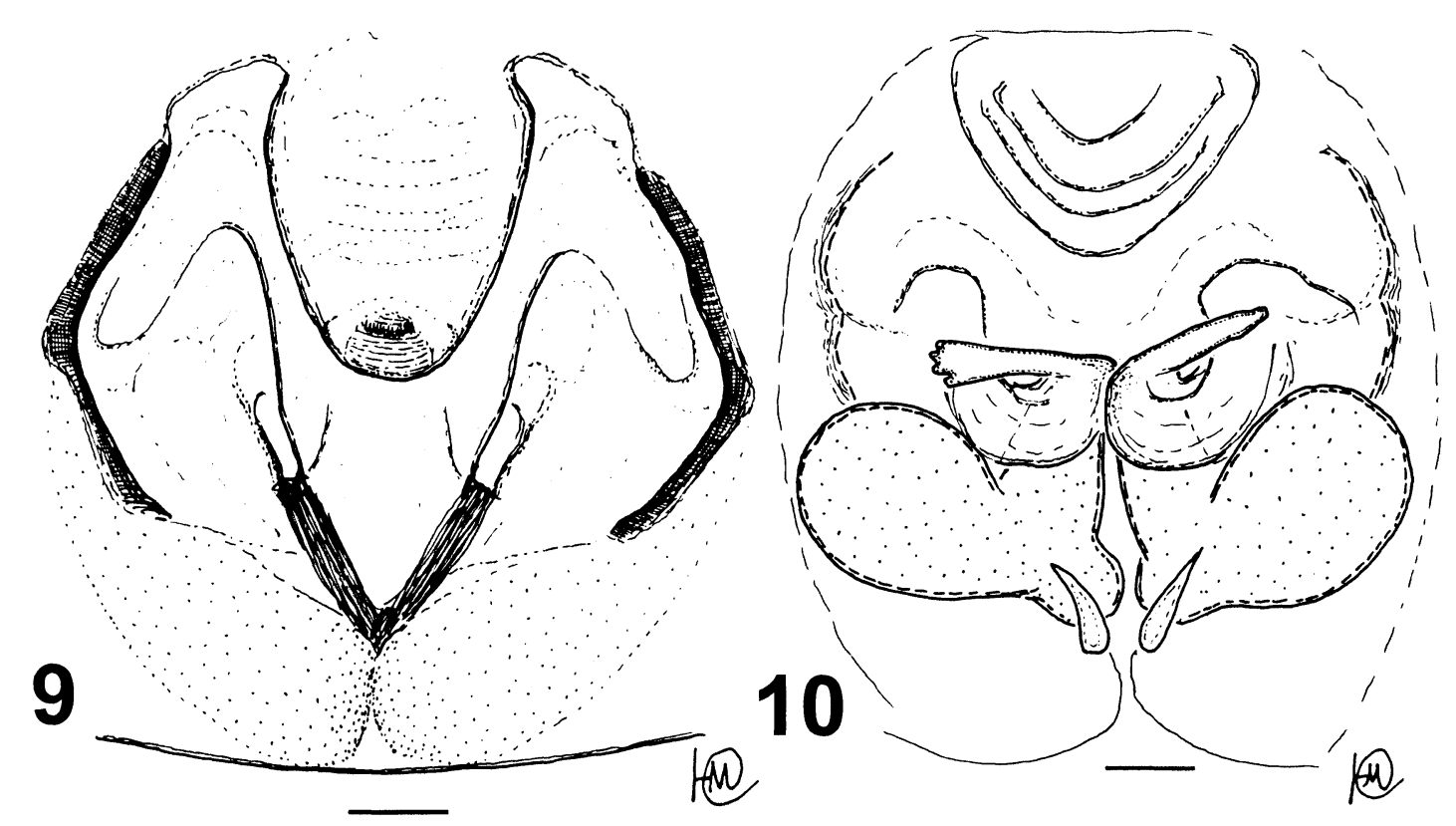

Figs. 9-10. Epigyne of Gnaphosa banini sp. n. -9, ventral view; 10, dorsal view. Scale: $0.1 \mathrm{~mm}$.

width 0.24 , back width 0.27 . Leg spination: leg I: femur p0-0-1, tibia v0-0-2, metatarsus v2-0-0; II: femur p0-1-1, tibia v1-2-2, metatarsus 2-0-0; III: femur p\&r0-1-1, patella r1, tibia d1-0-0, p2-1-1, v2-2-2, metatarsus p\&r1-21; IV: femur p\&r0-1-1, tibia d1-0-0, patella $r 1$, tibia p\&r2-1-1, v2-2-2, metatarsus p1-2-2, r2-2-2, v2-2-2. Palp as in Figs. 1-3 with 2 bulbal apophyses: median apophysis and apopysis of embolic base (=functional conductor sensu Ovtsharenko et al 1992). Apophysis of embolic base elongate (length/width ratio $=2$ ) with billshaped tip. Embolus strait with tubercle on the mid part of inner side. Tibial apophysis long, reaching the level of base of median apophysis.

Female. Total length 7.5. Carapace 3.3 long, 2.5 wide. Femur II 1.85 long. Eye sizes and interdistances: AME 0.09, ALE 0.09, PME 0.10, PLE 0.09, AME-AME 0.10, AME-ALE 0.02, PME-PME 0.09, PME-PLE 0.16, ALE-PLE 0.21, MOQ 0.30, front width 0.25 , back width 0.28 . Legs spination same as in male except tibia II v0$0-1$. Epigyne as in Figs. 9-10 with elongate scape (length/width ratio $=1.25$ ), rounded on the tip.

Habitats. In Bayankhongor Aimak specimens were collected by pitfall traps in dry (dried by winter frosts) meadow and under bushes on lakeshore, and by hand picking on pebbly lakeshore, on moist and cold screes $2800-3000 \mathrm{~m}$, in moss in mountain tundras $2800 \mathrm{~m}$ as well as in grass and under stones in mountain tundra 2800-3000 m.

Etymology. The species name is a patronym in honor of the first author's friend and expedition partner in Mongolia, Dr. Dmitry Banin, Seattle.

Comments. G. banini sp. n. belongs to the borea species group of Gnaphosa (sensu Ovtsharenko et al. 1992) to which 4 species were originally assigned: borea Kulczyński 1908, chola Ovtsharenko \& Marusik 1988, microps Holm 1939 and orites Chamberlin 1922. In some respects this group resembles the leporina group which was erected by Ovtsharenko et al. (1992), which includes 3 species: leporina (L. Koch 1866), pseudoleporina Ovtsharenko et al. 1992 and petrobia L. Koch 1872. These two groups have large apophysis associated with the base of the embolus (cf. Figs. 1-6, 8, 14-18). Other species of Gnaphosa do not have this character. The two groups have also other affinities: short embolus situated in the distal part of male palpal bulb, tubercle on embolus, hook like median apophysis, and long (more than half length of cymbium) tibial apophysis (except G. borea), relatively long (longer than wide) scape rounded at the end and long lateral pockets of epigynal fovea. It seems that after more detailed study it might be possible to revalidate Lohmander's subgenus Oreognaphosa Lohmander 1945 (type species: Gnaphosa leporina), which was originally proposed for leporina, petrobia, and holmi Tullgren (= G. orites).

Members of the borea group have an exclusively north Holarctic distribution and have either arctomontane, arcto-boreal or boreo-montane distribution. Records of this group south of $55^{\circ} \mathrm{N}$ are restricted to 
altitudes of more than $1 \mathrm{~km}$ above sea level. Within this group G. orites has the northernmost distribution. It was found on Wrangel Island and at the mouth of Lena River (ca. $72^{\circ} \mathrm{N}$ ). There is a similar pattern in Nearctic, where northernmost records of this species were reported from $70^{\circ} \mathrm{N}$ (Platnick \& Dondale 1992). All species of the borea group, except the new one, have wide ranges, Holarctic: microps and orites, Siberio-Nearctic: borea, or Siberian: chola.

Gnaphosa chola Ovtsharenko \& Marusik 1988

(Fig. 6-7. Map 2)

G. chola Ovtsharenko \& Marusik 1988, p. 209, f. 18-19, 21, 23, 25 (D令우); Ovtsharenko et al. 1992, p. 58, f. 199-202 (소우); Ovtsharenko \& Marusik 1996, p. 118, pl. 3, f. 2, 6, 10 (수우).

Material examined. 38수우 (IBPN), RUSSIA, Magadan Area, $29 \mathrm{~km} \mathrm{~N}$ of Magadan, Snow Valley Vil., Dukcha River valley (ca. $151^{\circ} \mathrm{E}, 59^{\circ} 43^{\prime} \mathrm{N}$ ), Summer 2000 (S. P. Bukhkalo). 4소 1우 (ZMUT), MONGOLIA, [12] Arkhangai Aimak., Ondrer-Ulaan, Tsakhir, Chulut Gorge, 4807'N, $100^{\circ} 22^{\prime} \mathrm{E}, 2100 \mathrm{~m}, 10-13.06 .1997$ (Yu. M. Marusik).
Comments. This species has a Siberian boreal range and is distributed from Tuva and Krasnoyarsk Province in the west, northeast to upper Kolyma (Marusik et al. 1992), southward to Arkhangai, Mongolia and Maritime Prov. of Russia (Marusik et al. 2000). Everywhere it is a rather rare species, but in environs of Magadan it was found recently in fairly large quantity.

\section{Gnaphosa gracilior Kulczyński 1901}

(Map 1)

G. gracilior: Ovtsharenko et al. 1992: p. 49, f. 169-170, 173-176 (우, D令, S); Marusik \& Logunov 1995, p. 188,

f. 40-46 (수우); Song et al. 1999, p. 448, f. 260P, 261D (우우).

G. proxima: Marusik \& Logunov 1995: 189, f. 47-50 (사우).

Material examined. 1§ (ISEA), RUSSIA, SE Altai, $2 \mathrm{~km}$ SE of Kosh-Agach, 27.06.1996 (R. Dudko).

Comments. This species has a Siberian polyzonal range and occurs from Xinjiang and South Gobi in the south-west, northward to Nizhnyaya Tunguska River, northeast to Kolyma River mouth, Chukotka $\left(69^{\circ} \mathrm{N}\right.$, Ovtsharenko et al. 1992) and southeast to Sakhalin Isl.

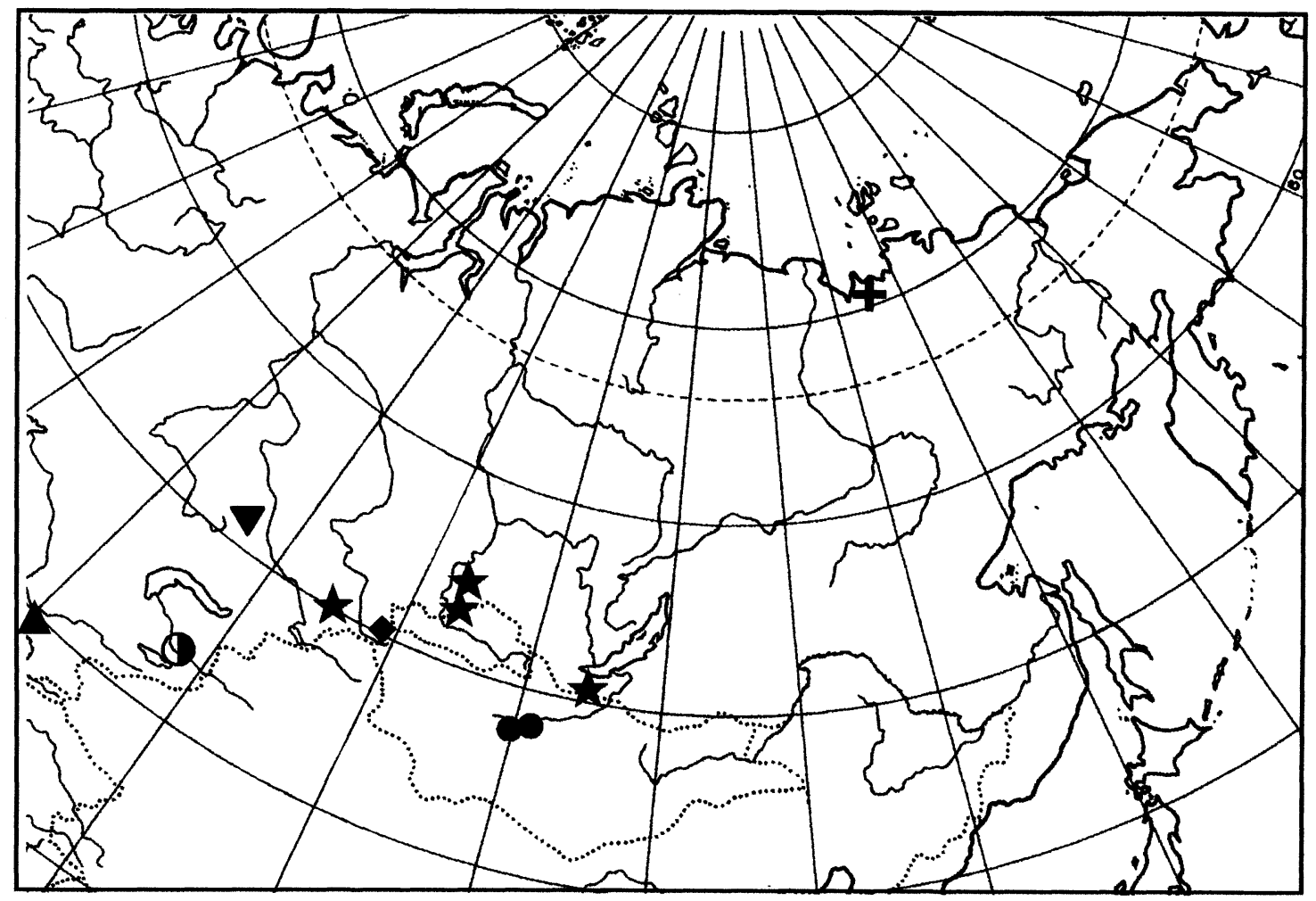

Map 1. New records of Gnaphosa species. G. banini sp. n. - (all the known localities); G. gracilior $\diamond ;$ G. ilika $-\mathbf{\Delta}$; G. lucifuga \& G. steppica $-\boldsymbol{\nabla} ;$ G. microps, G. nigerrima \& G. sticta -+ ; $G$. pseudoleporina - $\star$ (all the known localities); G. reikhardi - . 
(Marusik et al. 1993b). This record from Altai is the north-westernmost locality of the range.

Gnaphosa ilika Ovtsharenko, Platnick \& Song 1992

(Figs. 11-13. Map 1)

G. ilika Ovtsharenko et al. 1992, p. 82, f. 287-288, 297-300

(D令우).

Material examined. 1令 (ISEA), UZBEKISTAN, Turkestanski Mt. range, Zaamin Nat. Reserv. $39^{\circ} 36^{\prime} \mathrm{N}, 68^{\circ}$ 22’E, 2100 m, 10.06.1997 (D. Milko).

Comments. Until recently this species was known only from Kazakhstan and Kyrgyzstan (Platnick 2000).
The new record extends known range both to the west and south.

Gnaphosa lucifuga (Walckenaer 1802)

(Map 1)

Material examined. 12솨우 (ISEA), KAZAKHSTAN, Pavlodar Area, $\sim 1 \mathrm{~km} \mathrm{~W}$ of Yermak (=Aksy), $52^{\circ} 03^{\prime} \mathrm{N}$, $76^{\circ} 55^{\prime} \mathrm{E}, 14-28.06 .1998$ (A. B. Gromov \& O. V. Lyakhov).

Comments. This species has a west Palaearctic distribution. It was previously known to occur from France to north-central Kazakhstan (Kokchetav), and southward to Uzbekistan (Ovtsharenko et al. 1992). The present re-
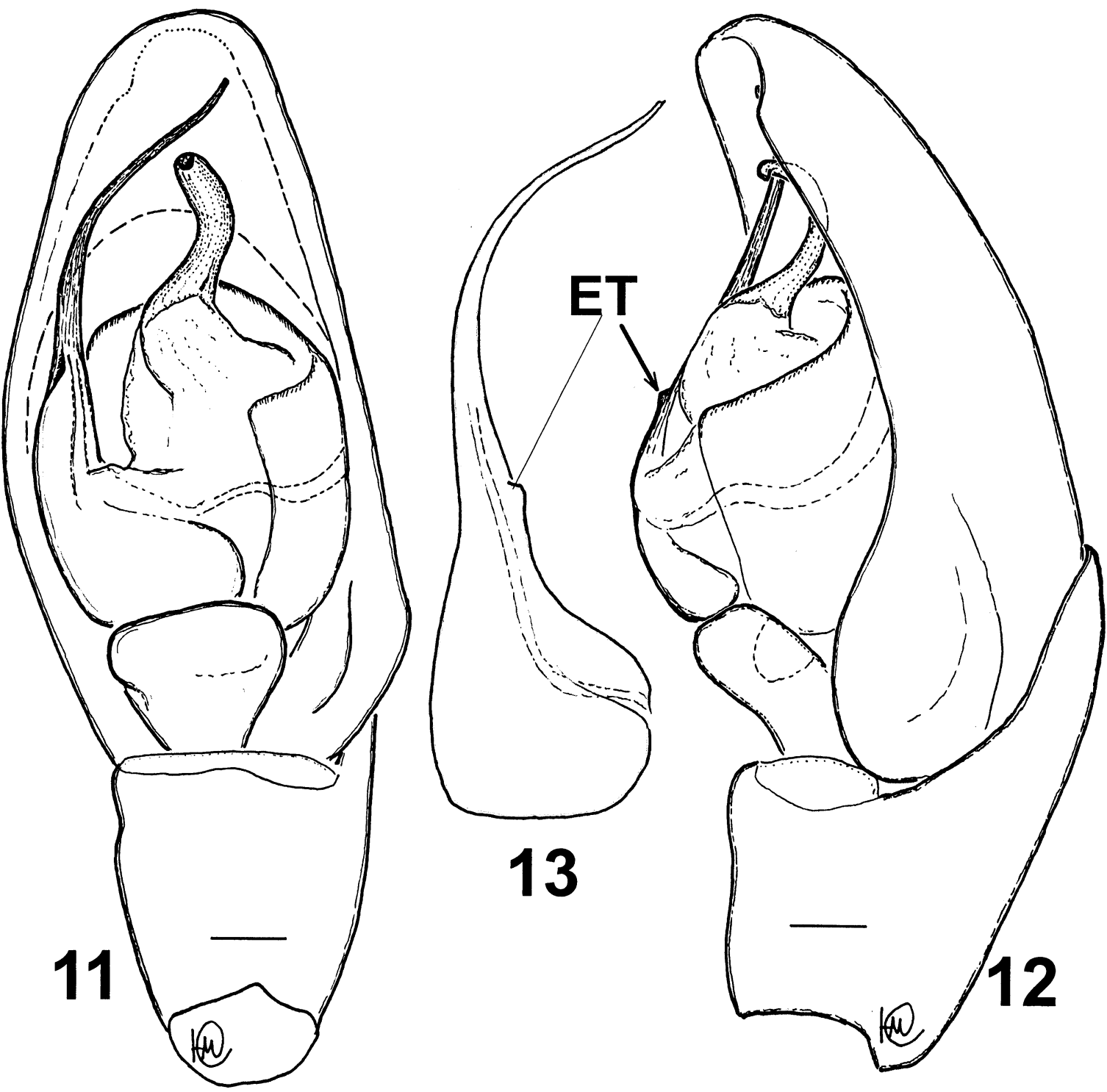

Figs. 11-13. Male left palp of Gnaphosa ilika. - 11, ventral view; 12, retrolateral view; 13, embolus, prolateral view. Scale: $0.1 \mathrm{~mm}$. Abbreviation: ET - embolic tooth. 
cord extends the known range of this species about $8^{\circ}$ to the east long. Specimens from Yermak Vill. are remarkably large. Males reach 18-19 mm (contra 11.114.9 in Europe, Grimm 1985) in total length, their carapaces reach length $8.0-8.5 \mathrm{~mm}$ (contra 5.3-6.8 in Europe, Grimm 1985). However, no differences have been found between West Siberian and European specimens in the shape of copulatory organs.

\section{Gnaphosa microps Holm 1939}

(Fig. 5. Map 1)

G. microps: Tullgren 1946, p. 90, pl. 15, f. 182-184 (令穴); Ovtsharenko \& Marusik 1988 p. 205, f. 1-3 (수우); Platnick \& Dondale 1992, p. 179, f. 272-275 (수우); Ovtsharenko et al. 1992, p. 59, f. 189-190, 203-206 (소우).

Material examined. 4ㅅํ우 (ZMUT), RUSSIA, Yakutia, north Yakutia, Yana River down flow, Kular Vill. environs, $70^{\circ} 35^{\prime} \mathrm{N}, 134^{\circ} 34^{\prime}$ E, July 1996 \& 1997 (N. N. Vinokurov).

Comments. This species has Circumholarctic hypoarcto-boreal range: from the highlands of Central Europe to Fennoscandia, throughout Siberia to Chuotka Peninsula, northward to Lena River mouth, and southward to Tuva and North Mongolia (Marusik et al. 1992; Ovtsharenko et al. 1992; Logunov et al. 1998). In Nearctic south to Colorado and New England (Platnick \& Dondale 1992). Among the previous records, one from the Lena River Delta (about $72^{\circ} 15^{\prime} \mathrm{N}$, Marusik et al. 1993a) is more northerly than the present new record.

\section{Gnaphosa nigerrima L. Koch 1878}

(Map 1)

G. nigerrima: Tullgren 1946, p. 88, f. 27B, pl. 14, f. 176-178 (ㅅㅇㅇㅜ); Grimm 1985, p. 77, f. 50, 52-53 (令实); Ovtsharenko \& Marusik 1988, p. 207, f. 12-14 (令早); Ovtsharenko et al. 1992, p. 80 , f. 285-286, 293-296 (소우).

Material examined. 2\} (IBPN), RUSSIA, Yakutia, north Yakutia, lower Yana River, Kular Vill. environs, $70^{\circ} 35^{\prime} \mathrm{N}$ 134³4'E, July 1996 \& 1997 (N. N. Vinokurov).

Comments. This species has a trans-Palaearctic hypoarcto-boreal range and is known in Siberia from Tuva (Marusik et al. 2000) northeast to the Chaun Bay (Marusik et al. 1992). The new record from Yana River extends the known range more than 2 degrees to the north in comparison to the Chaun Bay.

\section{Gnaphosa orites Chamberlin 1922}

(Fig. 4. Map 2)

G. holmi Tullgren 1946 , p. 89 , f. 27 C, pl. 14 , f. $179-181$ (소, D우).

G. orites: Ovtsharenko \& Marusik 1988, p. 208, f. 4-6 (合穴, S); Platnick \& Dondale 1992, p. 186, f. 284-287 (令实); Ovtsharenko et al. 1992, p. 60, f. 207-212 (ㅅㅇㅇㅜ).

Material examined. $3 \hat{\delta} 2$ ㅇ (ZMUT), FINLAND, Utsjoki, Kevo, Jesnalvaara, $69^{\circ} 45^{\prime} \mathrm{N}, 300 \mathrm{~m}$, alpine heath, 26.06. 12.09.1972 (S. Koponen). 11 (ISEA), RUSSIA, Tuva, 30-35 km SE of Mugur-Aksy, Mongun-Taiga Mt., 3100-3300m, 23.07.1993 (D. V. Logunov); 4^(ISEA), RUSSIA, Irkutsk Area, Cherski Mt., $15 \mathrm{~km} \mathrm{~S}$ of Slyudyanka, $51,538^{\circ} \mathrm{N}, 103$, $664^{\circ} \mathrm{E}, 1600 \mathrm{~m}, 16-25.07 .1984$ A. V. Barkalov.

Comments. Previously this species was known to have a Circumholarctic hemiarctic range. In Siberia it was recorded from the Polar Urals southward to north Cisokhotia $\left(59^{\circ} \mathrm{N}\right)$, northward to the Lena River Delta $\left(72^{\circ} \mathrm{N}\right)$ and Wrangel Island $\left(71^{\circ} \mathrm{N}\right)$ and eastward to the Bering Strait. In Europe this species was recorded from northern Fennoscandia $\left(69^{\circ} 45^{\prime}\right.$, Koponen 1977). In the Nearctic this species is known from highlands of Wyoming (ca. $45^{\circ} \mathrm{N}$ ) and New England (ca. $44^{\circ} \mathrm{N}$ ) and northward to the Mackenzie River delta (Platnick \& Dondale 1992). It is the northernmost true gnaphosid (Micaria constricta Emerton 1894 from Spitsbergen and Arctic Canada is not accounted). The discovery of this species in Cisbaikalia and Tuva extends the known range of this species in Palaearctic about 10 degrees to the south.

In several populations in the Magadan Area (upper Kolyma, and vicinity of Magadan) we have observed two size morphs with carapace of adult male about 3.5 $\mathrm{mm}$ and $2.5 \mathrm{~mm}$ long respectively. These two morphs differ in size of the palps also. There is no overlap between them. In the subgoltsy zone (transitional zone between mountain tundra and forest) they occur in the same samples, while in mountains only the small morph is found. Size difference are most probably caused by a different number of molts. Similar discrete size morphs have been observed in Xysticus britcheri Gertsch 1934 (Thomisidae) and few other species (Marusik unpublished). 
Gnaphosa pseudoleporina Ovtsharenko,

Platnick \& Song 1992

(Figs. 14-18. Map 1)

G. pseudoleporina Ovtsharenko et al. 1992, p. 68, f. 247-250 (D송ㅇ).

Material examined. 1^ (ISEA), RUSSIA, Altai, Kholzun Mt. Range, upper reaches of left tributary of Bannaya River, 2000-2500 m, 13-14.06.1999 (A. \& R. Dudko). 1수우 (ZMUH), RUSSIA, Irkutsk Area, Cherski Mt., $51,538^{\circ} \mathrm{N}$, $103,664^{\circ} \mathrm{E}$, moist meadow on slope, 18-25.07.1984 (K. Mikkola).

Comments. This species has a north Mongolian range and is distributed from Altai to southern Cisbaikalia. Previously this species was known only from West Sayan and Khakassia (Ovtsharenko et al. 1992). Our records extend its known range to the west (Altai) and to the east (Cherski Mt.).

\section{Gnaphosa reikhardi Ovtsharenko,} Platnick \& Song 1992

(Map 1)
G. reikhardi Ovtsharenko et al. 1992, p. 76 , f. $245,275-278$ (D송우).

Material examined. KAZAKHSTAN, Alma-Ata Area: 1

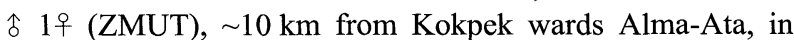
valley under stones, 22.04.1990 (M. I. Saaristo); 1시우 (ZMMU), Chilik Distr., Charyn Canyon, 21.04.1990 (M. I. Saaristo).

Comments. These samples were taken near the type locality.

Gnaphosa similis Kulczyński 1926

(Map 2)

G. similis Kulczyński 1926, p. 42, pl. 2, f. 6 (D우); Marusik \& Koponen 2000, p. 59, f. 9, 12-13 (令우).

G. muscorum: Ovtsharenko et al. 1992, f. 149-?150 (令우); Marusik \& Logunov 1995, f. 55-56 (ㅇ); Ovtsharenko \& Marusik 1996, f. 3. 9, 17 (ㅇํ우).

Material examined. 7^ (HMNH), MONGOLIA, Khentei Aimak: Ondorhantol, 80 km E'ny-ra, Edemi-Han hegyisop, 13.05-16.06.1979 (Z. Peregi). RUSSIA: 1令 (ZMUT), Buryatia, Jirga Field Station, $54^{\circ} 55^{\prime} \mathrm{N}, 111^{\circ} 07^{\prime} \mathrm{E}, 600 \mathrm{~m}$, 11.07.1996 (M. Uusitalo); 1우 (ZMUT), Buryatia, Barguzin Mt. Range, Olso River, 5452’N, 11055'E, 950 m, 7.07.1996 (M. Uusitalo); 9ㅅㅇㅇㅜ (IBPN), Yakutia, Kolyma River mouth

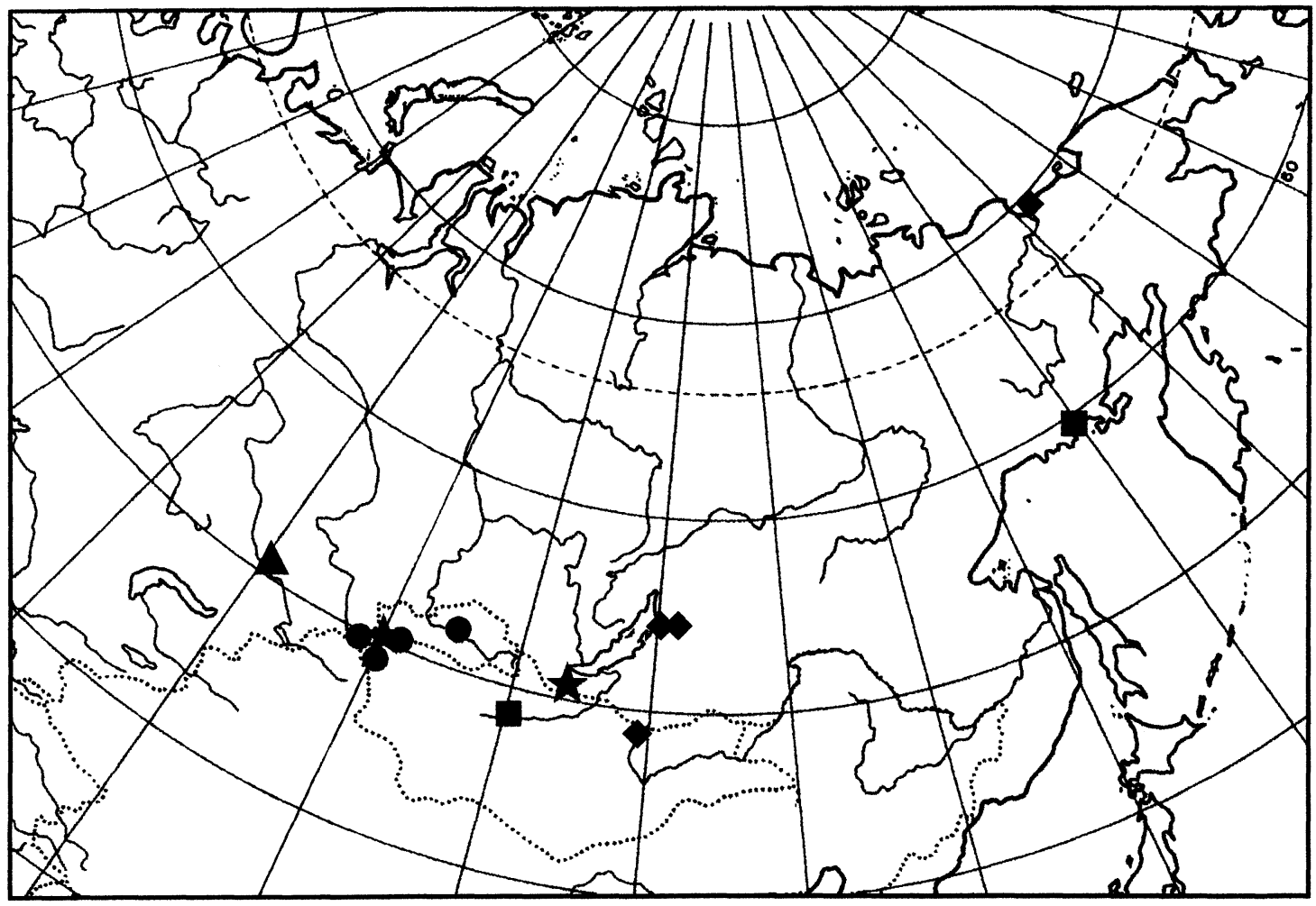

Map 2. New records of Gnaphosa species. G. chola $-\square$; G. orites $-\star$; G. similis $-\downarrow$; G. taurica $\mathbf{\Delta}$; G. tuvinica - (all the known localities). 


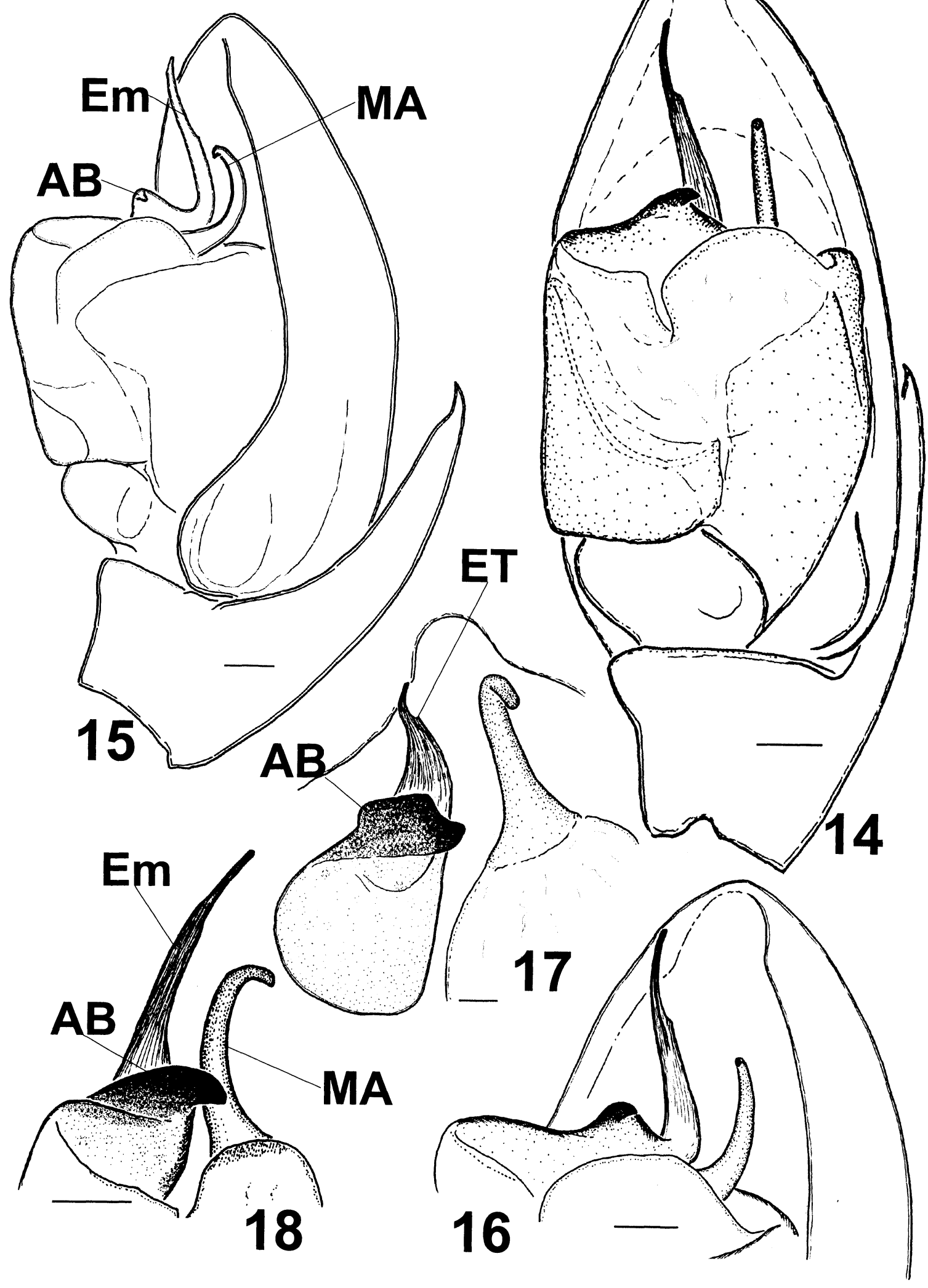

Figs. 14-18. Male left palp of Gnaphosa pseudoleporina - 14, ventral view; 15, retrolateral view; 16-18, apical part of palp, different turns. Scale: $0.1 \mathrm{~mm}$. Abbreviations: $\mathrm{AB}-$ apophysis of the embolic base; $\mathrm{Em}-\mathrm{em}-$ bolus, ET - embolic tooth, MA - median apophysis. 
part, environs, Krai Lesa \& Krutaya Dresva Vill. (161 20 ' E, 69¹0’N), cryo-xoremorphic habitats, July 1999 (A. V. Alfimov).

Comments. This species has east Siberian (BaikaloManchurian) boreal range: from Chukotka in the north $\left(69^{\circ} \mathrm{N}\right.$, sub G. muscorum, Marusik et al. 1992) southward to Maritime Province (sub G. muscorum, Ovtsharenko et al. 1992) and westward to East Mongolia and Transbaikalia (Chita Area and Buryatia).

Gnaphosa steppica Ovtsharenko, Platnick \& Song 1992 (Map 1)

G. steppica Ovtsharenko et al. 1992, p. 37, f. 127-128, 133136 (D송ㅇ).

Material examined. 1소웅 (ISEA), KAZAKHSTAN, Pavlodar Area, $1 \mathrm{~km}$ W of Yermak (=Aksu) Vill., 52 $03^{\circ}$ ' N, 7655'E, 14-28.06.1998 (A. V. Gromov).

Comments. This record extends the known range of this species about 8 degrees to the east. Previously this species was known to occur from Turkey to northcentral Kazakhstan (Kokchetav), northward to Saratov (Ovtsharenko et al. 1992).

\section{Gnaphosa sticta Kulczyński 1908}

(Map 1)

G. sticta: Ovtsharenko \& Marusik 1988, p. 208, f. 16-17, 20 (수우); Ovtsharenko et al. 1992, p. 48, f. 163-168 (숭ㅇ); Ono 1994, p. 189, f. 1-4 (수우); Ovtsharenko \& Marusik 1996, p. 117, pl. 3, f. 8,14 (令平).

Material examined: 4소우 (ZMMU), RUSSIA, Yakutia, north Yakutia, Yana River down flow, Kular Vill. environs, 70³5'N, 134³4'E, July 1996 \& 1997 (N. N. Vinokurov).

Comments. The lower Yana River is the type locality of this species and northernmost point of its distribution.

\section{Gnaphosa taurica Thorell 1875}

(Map 2)

G. taurica: Ovtsharenko et al. 1992, p. 22, f. 63-64, 71-74 (수우); Song et al. 1999, p. 451, f. 262K, P (상ㅇ).

Material examined. 1今े (ISEA), KAZAKHSTAN, Akmola Area, Balkhash Distr., $1 \mathrm{~km}$ E of Petrovka Vill., pine forest opening, 1.06.1999 (A. Gromov).

Comments. This species ranges from Bulgaria to China (Ovtsharenko et al. 1992). Our record from the Akmola Area seems to be the northernmost in Asia.
Gnaphosa tuvinica Marusik \& Logunov 1992

(Map 2)

G. tuvinica: Marusik \& Logunov in Ovtsharenko et al. 1992, p. 28, f. 91-94 (D令우); Marusik \& Logunov 1995, p. 191, f. 57-60 (송우).

Material examined. 1§(ISEA), RUSSIA, SE Altai, 28 $\mathrm{km} \mathrm{S}$ of Kosh-Agach, Chagan-Burgazy River valley, 29.06.1996 (R. \& A. Dudko). 4우 (HMNH), MONGOLIA, Bajan-Ölgij Aimak, ca. $20 \mathrm{~km} \mathrm{~S}$ von Somon Cagannuur, $2300 \mathrm{~m}$, Hochgebirgssteppe, Östlicher Berghang mit niedrigen, spurlich wachsenden Pflanzen, unter Steinen geeinzelt 30.VI.1968 (Z. Kasab).

Comments. The presence of this species in Mongolia was first indicated in our work (Marusik et al. 2000) without precise material data. The record from Altai extends slightly, about $100 \mathrm{~km}$, its the known range (from West Tuva southwest to Bayan-Olgiy Aimak in Mongolia: Marusik et al. 2000) to the west.

\section{Acknowledgments}

We wish express our deep gratitude to all colleagues who provided us with unidentified and/or comparative material, especially to D. V. Logunov (ISEA, Novosibirsk). We wish to thank to D. J. Buckle (Saskatoon) for checking and editing English. This work was supported in part by the Academy of Finland (grant \#49225) and the Russian Foundation for Basic Research (grant \#01-04-48989)

\section{References}

Grimm, U. 1985. Die Gnaphosidae Mitteleuropas (Arachnida, Araneae). Abh. Naturw. Ver. Hamb., 26: 1318.

Koponen, S. 1977. Spider fauna (Araneae) of Kevo area, northernmost Finland. Rep. Kevo Subarctic Res. Stat., 59: $48-62$.

Kulczyński, V. 1926. Arachnoidea camtschadalica. Ann. Mus. Zool. Acad. Sci. USSR, 27(1): 29-72.

Logunov, D. V., Marusik, Y. M. \& Koponen, S. 1998. A check-list of the spiders in Tuva, South Siberia with analysis of their habitat distribution (Arachnida: Araneae). Ber. Nat.-med. Verein Innsbruck, 85: 125159.

Lohmander, H. 1945. Vorlaufige Spinnennotizen. Ark. Zool., 35(16): 1-21.

Marusik, Y. M., Eskov, K. Y. \& Kim, J. P. 1992. A checklist of spiders (Aranei) of Northeast Asia. Korean Arachnol., 8(1/2): 129-158.

Marusik, Y. M., Eskov, K. Y., Koponen, S. \& Vinokurov, N. N. 1993a. A check-list of the spiders (Aranei) of Yakutia, Siberia. Arthropoda Selecta, 2(2): 63-79. 
Marusik, Y. M., Eskov, K. Y., Logunov, D. V. \& Basarukin, A. M. 1993b. A check-list of spiders (Arachnida Aranei) from Sakhalin and Kurile Islands. Arthropoda Selecta, 1(4): 73-85.

Marusik, Y. M. \& Koponen, S. 2000. Circumpolar diversity of spiders: implications for research, conservation and management. Ann. Zool. Fennici, 37: 265-269.

Marusik, Y. M. \& Logunov, D. V. 1995. Gnaphosid spiders from Tuva and adjacent territories, Russia. Beitr. Araneol., 4: 177-210.

Marusik, Y. M. \& Logunov, D. V. 1998. On the spiders (Aranei) collected in central Mongolia during a joint American-Mongolian-Russian expedition in 1997. Arthropoda Selecta, 7(3): 233-254.

Marusik, Y. M., Logunov, D. V. \& Koponen, S. 2000. Spiders of Tuva, South Siberia. IBPN FEB RAS, Magadan. 252 pp.

Mikhailov, K. G. 1997. Catalogue of the Spiders of the Territories of the Former Soviet Union (Arachnida, Aranei). Zool. Mus. of the Moscow State Univ., Moscow. 416 pp.

Ono, H. 1994. Gnaphosid spiders mainly from the Daisetsuzan Mountains, Hokkaido, Japan. Acta Arachnol. 43: 183-191.

Ovtsharenko, V. I. \& Marusik, Y. M. 1988. Spiders of the family Gnaphosidae (Aranei) of the north-east of the USSR (the Magadan Province). Ent. Obozr., 67(1): 204217. [In Russian]

Ovtsharenko, V. I. \& Marusik, Y. M. 1996. Additional data on the spiders of the family Gnaphosidae (Aranei) of the north-east of Asia. Entomological Studies in the NorthEast of the USSR. USSR Acad. of Sci., Instit. of Biol. Problems of the North, Vladivostok: 114-130. [In Russian]

Ovtsharenko, V. I., Platnick, N. I. \& Song, D. X. 1992. A review of the North Asian ground spiders of the genus Gnaphosa (Araneae, Gnaphosidae). Bull. Am. Mus. Nat. Hist., 212: 1-88.

Platnick, N. I. 2000. The World Spider Catalog. American Museum of Natural History: http://research.amnh.org/ entomology/spiders/catalog81-87/

Platnick, N. I. \& Dondale, C. D. 1992. The insects and arachnids of Canada, Part 19. The ground spiders of Canada and Alaska (Araneae: Gnaphosidae). Res. Branch, Agr. Canada, 1875: 1-297.

Platnick, N. I. \& Shadab, M. U. 1975. A revision of the spider genus Gnaphosa (Araneae, Gnaphosidae) in America. Bull. Am. Mus. Nat. Hist., 155: 1-66.

Song, D. X., Zhu, M. S. \& Chen, J. 1999. The Spiders of China. Hebei Sci. Technol. Publ. House, Shijiazhuang. $640 \mathrm{pp}$.

Tullgren, A. 1946. Svensk spindelfauna: 3. Egentliga Spindlar. Araneae. Fam. 5-7. Clubionidae, Zoridae och Gnaphosidae. Entomologiska Foreningen, Stockholm. $141 \mathrm{pp}$.

Received March 10, 2001 / Accepted August 30, 2001 


\section{Acta Arachnologica Vol. 50, No. 2 掲載論文の和文要旨}

タニマノドヨウグモの放置網に侵入する造網性クモ類 の侵入頻度の季節的変化 (pp. 117-122)

吉田 真（干525-8577 滋賀県草津市野路東 1-1 立 命館大学理工学部生物工学科)

クモ網への造網性クモ類の侵入に関与する諸要因を 明らかにするために，タニマノドヨウグモが放置した 網へ侵入する造網性クモ類の頻度の季節的変化を調べ た. 関与する要因として，ホスト網のサイズと密度, 侵入種の生活史之密度が調べられた。侵入者はおあに, タニマノドヨウグモの仔グモとさまざまなサイズのア シナガグモであった．網あたりの侵入者数の平均は, 侵入種の密度が低くホス卜網の密度が高いために，4 月から 6 月までは低かった。これに対して 7 月から 9 月上旬にかけては, 侵入者は非常に多かった。これは, ホスト網の密度が低いことと, 7 月に生まれたタニマ ノドョウグモの仔グモの出現によると思われる，この ように, 侵入頻度は一義的には, ホス卜網の密度と侵 入種の密度に依存していると思われる。

\section{中国のアシダカグモ科 1. 新シノニムと転属, タイプ} 指定つき， 既知種のリスト（pp. 123-134）

Peter Jäger', Chang-Min Yin ${ }^{2}$ ('Institut für Zoologie, Johannes Gutenberg-Universität, Germany; ${ }^{2}$ Hunan Normal University, P. R. China)

中国のアシダカグモ科の最初の分類学的改訂として, これまでに中国から記録されている 3 亜科 8 属 51 種 のリストを掲げた。個々の種の詳細なタイプ標本のデー 夕，既知分布を示した．次の種について転属をおこなっ た : Olios menghaiensis (Wang 1990), Olios tiantongensis (Zhang \& Kim 1996), Pseudopoda bibulba (Xu \& Yin 2000) Sinopoda dayong (Bao, Yin \& Yan 2000 (以上旧 Heteropoda), Olios nanningensis (Hu \& Ru 1988)（旧 Micrommata), Pseudopoda marsupia (Wang 1991)（旧 Sinopoda). 次の種は新規にシノニムと認められた： Heteropoda guangdongensis Yin, Yan \& Kim 2000 は Olios nanningensis ( $\mathrm{Hu} \& \mathrm{Ru} 1988) の$, Micrommata hainanensis $\mathrm{He} \& \mathrm{Hu} 2000$ は Olios nanningensis (Hu \& $\mathrm{Ru}$ 1988) の, Heteropoda shimen Yin, Peng, Yan \& Bao 2000 は Heteropoda venatoria (Linnaeus 1767) の, Thelcticopis jiulongensis Zhang \& Kim 1996 は Thelcticopis severa（L. Koch 1875）のそれぞれジュニ
アシノニム. 次の種のシンタイプ, レクトタイプ, パ ラレクトタイプを指定した：Pseudopoda exiguoides (Song \& Zhu 1999), Sinopoda pengi Song \& Zhu 1999, Sinopoda wangi Song \& Zhu 1999. また Heteropoda zhangi Song \& Zhu 1999 は無効学名である.（和訳 : 編集委員会）

\section{旧北区東部からのメキリグモ属（ワシグモ科）の 1 新 種と他の数種の新記録（pp. 135-144）}

Yuri M. Marusik ${ }^{1} \&$ Seppo Koponen² ('IBPN RAS, Russia; ${ }^{2}$ Zoological Museum, University of Turku, Finland)

ワシグモ科メキリグモ属 Gnaphosa の borea 種群に 属する 1 新種 $G$. banini をモンゴルから記載するとと もに, 本種群 (G. borea Kulczyński 1908, G. chola Ovtsharenko \& Marusik 1988, G. microps Holm 1939, G. oritis Chamberlin 1922, G. banini) の雄の識別形質を示 した. G. ilika Ovtsharenko et al. 1922, G. pseudoleporiona Ovtsharenko et al. 1992 の雄を図示した。 また, 旧北区東部からの他の Gnaphosa 属 9 種の生物地理学 的に興味のもたれる記録を掲げた。（和訳：編集委員 会）

全北区系のクモの 1 属 Procerocymbium Eskov 1989 （サラグモ科）の改訂（pp. 145-156）

Yuri M. Marusik ${ }^{1} \&$ Seppo Koponen ${ }^{2}$ (' IBPN RAS, Russia; ${ }^{2}$ Zoological Museum, University of Turku, Finland)

サラグモ科 Procerocymbium Eskov 1989 とその基準 種 $P$. sibiricum Eskov 1989 を再記載し, 3 新種 $P$. jeniseicum (中部シベリア), P. buryaticum (トランス バイカルと南ヤクーチア), P. dondalei (ユーコン地 方）を記載した。本属の他の属との関係についても論 議した.

（和訳：編集委員会）

日本産ヒメグモ亜科（クモ目：ヒメグモ科）の属およ び種の検討 (pp. 157-181)

吉田 哉（广990-2484 山形市篭田 2 丁目 7 番 16 号)

日本産のヒメグモ亜科 Theridiinae Sundevall 1833 の 属および種の検討をおこなった。 ヒメグモ亜科は雄触 肢の杯葉内側に頭巾状の小杯葉があることが特徽で, ほとんどの属に間疮がない. Monetinae Simon 1894 お 